\title{
S-Methyl Cysteine Protective Effects in Oreochromis Niloticus Fish Contaminated by Thiobencarb Herbicide
}

\author{
Mostafa Ali Elmadawy ${ }^{1^{*}}$, Walied Abdo ${ }^{2}$, Amira Alaa El-Dein Omar ${ }^{3}$, and Nadia B. Mahfouz ${ }^{4}$ \\ ${ }^{I}$ Department of Forensic Medicine and Toxicology, Faculty of Veterinary Medicine, Kafrelsheikh University, Kafrelsheikh, El Geish Street, 33516, Egypt \\ ${ }^{2}$ Department of Pathology, Faculty of Veterinary Medicine, Kafrelsheikh University, El-Geish street, 33516 Kafrelsheikh, Egypt. \\ ${ }^{3}$ Department of Fish Diseases and Management, Faculty of Veterinary Medicine, Kafr El-Sheikh University, El-Geish street, 33516 Kafrelsheikh, Egypt. \\ ${ }^{4}$ Department of Fish Diseases and Management, Faculty of Veterinary Medicine, Kafr El-Sheikh University, El-Geish street, 33516 Kafrelsheikh, Egypt. \\ *Corresponding author's Email: drmostox@yahoo.com; (D)RCiD: 0000-0002-7174-1370
}

\begin{abstract}
Thiobencarb which is a carbamate herbicide is used for managing undesirable weeds during rice cultivation in Egypt. This study was designed to investigate the adverse effects of a field dose of thiobencarb on Nile tilapia and ameliorating the role of the low dose of S-methyl cysteine (SMC). Experimental fishes were divided into four groups; first group was reared without any treatments and served as a control group; the second group was exposed to thiobencarb $(36 \mu \mathrm{g} / \mathrm{L})$; the third group was fed on a commercial feed containing $200 \mathrm{mg}$ of $\mathrm{SMC} / \mathrm{Kg}$ in conjunction with thiobencarb added to aquarium $(36 \mu \mathrm{g} / \mathrm{L})$ while, the fourth group was fed on a feed containing 200 $\mathrm{mg}$ of SMC/Kg only. Fishes were sacrificed at the end of the experimental course (two months) and sampling was carried out. Catalase, Glutathione S Transferase activities, Glutathione reduced, and Malondialdhyde levels were assayed. Genotoxic effect of thiobencarb and SMC on treated fish was investigated in erythrocytes, gills, and liver tissues using micronucleus and comet assay. Histopathological examination of livers, gills, and brain was also carried out. The results indicated that fish exposed to thiobencarb indicated herbicide dependent oxidative stress and genotoxic effect justified by a significant difference in antioxidant biomarkers as well as nuclear abnormalities and comet parameters compared to control values. Moreover, histopathological findings were in line with other results. SMC ameliorated the adverse effects which were effective in the improvement of DNA and oxidative damage in thiobencarb intoxicated fish.
\end{abstract}

Keywords: Carbamate, Fish, Genotoxic damage, Histopathology

\section{INTRODUCTION}

Potential exposure to the toxic chemicals has been progressively increased in the last decades. Scientists have increased their ecological researches in detecting and controlling the hazard chemical agents responsible for unacceptable damages to the ecosystems and human health (Munger et al., 1997; Gorell et al., 1998; Nwani et al., 2011; Nicolopoulou-Stamati et al., 2016). These agents may have adverse physiological, pathological or biochemical effects to living beings, some of them may possess a mutagenic potential which can express their action later in the next generation of the organisms (Anderson, 2005; Recio et al., 2010). Noxious weeds in common are the most remarkable and prevalent biological problem to crop production in rice fields which are commonly controlled by chemical herbicides (Sapari and Ismail, 2012; Hakim et al., 2015). These herbicides can strike their way to the water bodies through surface runoff (Phong et al., 2006; Papadakis et al., 2015) causing impacts on non-target organisms specially those living in the aquatic environment which differs according to degree of dispersion, concentration and toxicity of the herbicide (Van der Werf, 1996). The residues of these herbicides accumulate in the environment due to its widespread use over the last years which negatively damaged the aquatic organisms and living biota (Silva et al., 2019; Valadas et al., 2019).

Thiobencarb is a dithiocarbamate selective herbicide was developed by Kumiai Chem. Ind. Co. Ltd and introduced in the agricultural field to control the unwanted weeds in the rice fields in 1970 (Ishikawa et al., 1977). It has been used extensively by the farmers in Egypt particularly during the rice cultivation season. Previous studies have been conducted to assess the thiobencarb toxicity to the ecosystem (Bailey, 1993; Fernández-Vega et al., 1999; Saka, 2010).

Genotoxic and mutagenic effects of herbicides have been previously evaluated in several model organisms (Sanderson et al., 2001; Hladik et al., 2008; Benfeito et al., 2014) using several biomarkers for genotoxicity assessment, such as DNA adducts, chromosomal aberrations, DNA strands breaks, micronuclei formation and cell death induction (Stein et al., 1993; Sikka et al., 1990; Bombail et al., 2001). Oreochromis niloticus fish have been used in several studies as a model for genotoxicity investigation of various environmental pollutants (Lima et al., 2006; Kandiel et al., 2014; Bacolod et al., 2017). Several studies have been conducted implementing relatively simple methods to verify the mutagenic effects of the herbicides. The comet and micronuclei assays can be applied for evaluation of the genetic material damage in the experimental and field studies (Monteith and Vanstone, 1995). S-Methyl Cysteine (SMC) is an 
organosulfur compound naturally discovered in some plants particularly garlic (Allium sativum). A promising protective role of SMC had been prophesied as anti-apoptotic (Nasr et al., 2017), antidiabetic (Senthilkumar et al., 2013) and anticancer (Fukushima et al., 2001). However, a high dose of SMC may induce adverse effects (El-Magd et al., 2017). Present study, aimed to point out the genotoxicity of a field dose of thiobencarb on Oreochromis niloticus fish and its modulation by a low dose of SMC.

\section{MATERIALS AND METHODS}

\section{Ethical approval}

This study was conducted under the ethical approval from the Experimental Animal Care Committee in accordance with guidelines of Faculty of Veterinary Medicine, Kafrelsheikh University, Egypt.

\section{Chemicals}

A technical grade of thiobencarb (95\% purity) from Kafrelzyat Chemicals Company, Egypt was used in presenta experimental study. S-methyl cysteine was purchased from Sigma-Aldrich.

\section{Fish acquisition and maintenance}

One hundred and sixty Nile tilapia (Oreochromis niloticus) fish were used for this study. The average weight of fishes was $30 \pm 3.5 \mathrm{~g}$. The fish were purchased from a private fish farm in Kafrelsheikh governorate and then carefully transferred to the laboratory in water tanks filled with water from the fish collection source to avoid the stress of another water composition and temperature.

\section{Aquariums and fish rearing}

Fish were transferred to glass aquariums filled with dechlorinated water, each of them has 200-liter capacity. Fish were acclimatized to the lab conditions for 21 days. Fish were fed on commercial fish diet. Water was replaced every three days during the acclimation period.

\section{Experimental design}

Fish were divided into four groups; each group contains 40 fish and then each 40 fish divided into two aquariums (20 fish in each). Fish groups were treated as follows; first group (Control group), fish were exposed merely to dechlorinated tap water; second group, fish were exposed to $36 \mu \mathrm{g} / \mathrm{L}$ thiobencarb (this dose was determined as the average concentration of thiobencarb in 10 water samples collected from water drainage bodies near rice filed in Kafrelsheikh, Egypt using gas chromatography); third group, fish in each aquarium were provided every day with $15 \mathrm{~g}$ ration containing SMC $(200 \mathrm{mg} / \mathrm{Kg})$. Fourth group: fish were exposed to thiobencarb $(36 \mu \mathrm{g} / \mathrm{L})$ and fed on ration containing SMC (200 mg/kg). The experimental course endured 60 days. The water of all aquariums was replaced once a week during the experimental course. The particular herbicide concentration was supplied for the third and fourth groups whenever the water was changed. The laboratory conditions during the experimental period in common were Light period $\sim 12 \mathrm{hrs}$ and temperature $25 \pm 2^{\circ} \mathrm{C}$.

\section{Sampling}

Fishes were sacrificed at the end of experimental course (two months) and sampling was carried out. Eight fish samples were randomly collected from each group (four samples from each aquarium) at the end of experiment. Fishes were sufficiently dried by paper towels. Heparinized blood samples were collected from the caudal vein puncture for micronuclei analysis. Then fish samples were dissected. Liver and gills samples were picked up and divided into three sufficient parts. First one preserved on PBS buffer solution at $-80{ }^{\circ} \mathrm{C}$ for carrying out comet assay. Second part processed directly for antioxidants biomarkers assay and the third portion was properly preserved in formalin $10 \%$ for histopathological examination.

\section{Determining antioxidant biomarkers}

Mincing and homogenization of Liver and gill samples was carried out in phosphate buffer saline and $\mathrm{pH}$ 7.4. The homogenate was centrifuged at 4,000 rpm for 20 minutes and supernatants were isolated for measuring antioxidant biomarkers level which include Catalase (CAT), Glutathione S Transferase (GST) activities, total Glutathione reduced (GSH), and Malondialdehyde (MDA) which were assayed by utilizing specified methods described by Beutler et al. (1963), Habig et al. (1974), Ohkawa et al. (1979) and Aebi (1984).

\section{Micronuclei analysis}

Heparinized blood samples were immediately smeared on clean glass slides and then stained with Giemsa stain. Micronuclei was assayed according to the previously described method (Cavaş and Ergene-Gözükara, 2003). The 
number of 1,000 clearly separate cells from the neihboring were scored from each slide by using light microscope (labomed, USA) under $100 \times$ magnifications. Micronuclei were scored, if it was clearly separated from the nucleus (AlSabti and Metcalfe, 1995). Other nuclear abnormalities (blebbed nuclei, lobed nuclei, notched nuclei and binuclei) were recorded.

\section{Comet assay}

Single cell electrophoresis was carried out according to the published method (Singh et al., 1988). Briefly, $10 \mathrm{uL}$ of fish liver or gills homogenate were thoroughly mixed with $90 \mathrm{uL}$ of low melting point agarose $(0.7 \%$ in $\mathrm{PBS})$ at $37^{\circ} \mathrm{C}$. This prepared mixture was then added to a fully frosted microscope slide coated with 110 ul of normal melting point agarose (1\% in PBS). A cover slip was directly placed on top of the slide, and the agarose layer was allowed sufficiently to solidify for 10 minutes at $4^{\circ} \mathrm{C}$. Afterwards, the cover slip was carefully removed and a second layer of low melting point agarose without cells was added gently, a cover slip was applied, and the slide was held at $4^{\circ} \mathrm{C}$ for five minutes to allow the agarose layer to solidify. After removal of the cover slip, the slides were placed in lysis buffer $(2.5 \mathrm{~mol} / \mathrm{L}$ $\mathrm{NaCl}, 100 \mathrm{mmol} / \mathrm{L} \mathrm{Na} 2 \mathrm{EDTA}, 10 \mathrm{mmol} / \mathrm{L}$ Tris, (pH 10)) with freshly added $1 \%$ Triton X-100 and $10 \%$ DMSO for at least one hour at $4^{\circ} \mathrm{C}$. Later, slides were placed in the electrophoresis chamber and incubated with electrophoresis alkaline buffer $(300 \mathrm{mmol} / \mathrm{L} \mathrm{NaOH}, 1 \mathrm{mmol} / \mathrm{L} \mathrm{Na} 2 \mathrm{EDTA}, \mathrm{pH}>13)$ for 15 minutes at $4^{\circ} \mathrm{C}$ to allow DNA unwinding and the expression of alkali-labile DNA damage as strand breaks. Electrophoresis was for 30 minutes at $25 \mathrm{~V}$ and 300 $\mathrm{mA}$. The slides were washed three times, with $0.4 \mathrm{~mol} / \mathrm{L}$ Tris with $\mathrm{pH} 7.5$ as neutralization buffer. Finally, slides were stained with $50 \mathrm{uL}$ of ethidium bromide $(2 \mathrm{mg} / \mathrm{mL})$, covered with a cover slip and observed under $400 \times$ magnification with a Optika Axioskop fluorescent microscope.

From each sample, 100 randomly selected cells, respectively, were photographed and scanned. The scanned images were analyzed with the comet score analysis system. For each cell, the length of DNA migration (tail length) was measured in PX from the center of the nucleus to the end of the tail. The percentage of DNA in the tail was determined by measuring the total intensity (fluorescence) in the cells. The tail moment, expressed in arbitrary units which was calculated as tail length multiplied by percentage of migrated DNA/100.

\section{Histopathological examination}

Samples from the liver, gills and brain were collected from fish of various groups. The samples were fixed in $10 \%$ neutral buffered formalin, dehydrated in alcohol, cleared in xylene, embedded in paraffin and sectioned in $5 \mu \mathrm{m}$ thickness. Then serial sections were subjected to routine hematoxylin and eosin staining (Bancroft and Layton, 2013).

\section{Statistical analysis}

The data was analyzed by ANOVA procedures of the IBM SPSS software program (Version 16.0; IBM Corp., NY, USA). The differences between different means were estimated by the Duncan Multiple Range Test (DMRT). The differences among means with $\mathrm{p}<0.05$ were represented statistically as significant differences.

\section{RESULTS}

\section{Antioxidant biomarkers}

Catalase, GST activities, GSH and MDA level were demonstrated in homogenate samples from liver and gills of fish of all experimental groups. The results were presented in Figure 1. The CAT activity was significantly $(\mathrm{P}<0.05)$ decreased in both hepatic (3.38) and gill (3.32) tissues of thiobencarb treated fish compared to control fish (4.49) and (4.37), respectively. The inhibition of CAT activity was ameliorated by SMC concurrently with thiobencarb which was more prominent in gills than liver. GST activity was significantly elevated in thiobencarb intoxicated fish gills (0.44) and liver (0.36) compared to the control values (0.29) and (0.18), respectively. This elevation was diminished with SMC provided fish. GSH and MDA levels were increased significantly $(\mathrm{P}<0.05)$ in the gills and hepatic tissues of intoxicated fish over the control non treated fish. SMC provided in fish ration decreased the level of GSH and MDA compared to the intoxicated fish. Antioxidant biomarkers that measured in the fourth group were evidence to antioxidant system improvement by SMC.

\section{Micronuclei analysis}

The small non refractive parts that present in cytoplasm and are similar to the nucleus in staining is recorded as micronucleus, it is usually one particle fully separated from the nucleus. The determined percentage of micronuclei was significantly increased $(\mathrm{P}<0.05)$ in the second fish group which treated with thiobencarb, compared to the control group. The increased micronuclei level due to thiobencarb was relieved by SMC in the third group compared to the first and second group. Nuclear abnormalities were also recorded in the examined samples (Table 1). Binucleated cells and abnormal nuclei were significantly increased $(\mathrm{P}<0.05)$ in fish treated with thiobencarb compared to the control group, fish treated with SMC and thiobencarb revealed improvement in the effect on erythrocyte nuclei. The SMC provided groups revealed non-significant decrease $(\mathrm{P}>0.05)$ in nuclear abnormalities compared to the control group. 
Table 1. Nuclear abnormalities in erythrocytes of Oreochromis niloticus exposed to thiobencarb (36 $\mu \mathrm{g} / \mathrm{L})$ and SMC (200 $\mathrm{mg} / \mathrm{kg}$ ration) compared with control non treated fish

\begin{tabular}{|c|c|c|c|c|}
\hline $\begin{array}{ll}\text { Parameters } & \text { Groups } \\
\end{array}$ & Control & Thiobencarb & Thiobencarb + SMC & SMC \\
\hline Micronucleus (\%) & $0.032 \pm 0.0011^{\mathrm{b}}$ & $0.040 \pm 0.0015^{\mathrm{a}}$ & $0.033 \pm 0.0012^{b}$ & $0.030 \pm 0.0009^{b}$ \\
\hline Binucleated & $0.020 \pm 0.0012^{\mathrm{c}}$ & $0.037 \pm 0.0005^{\mathrm{a}}$ & $0.026 \pm 0.0009^{b}$ & $0.018 \pm 0.0011^{\mathrm{c}}$ \\
\hline Abnormal Nuclei & $0.012 \pm 0.0008^{\mathrm{c}}$ & $0.043 \pm 0.0012^{\mathrm{a}}$ & $0.023 \pm 0.0012^{b}$ & $0.012 \pm 0.0009^{c}$ \\
\hline
\end{tabular}

* Means with different superscripts in each row are significantly differ at $\mathrm{P}<0.05$. SMC means S-Methyl Cysteine

\section{Comet assay}

The DNA damage in liver and gills tissues of Oreochromis niloticus exposed to thiobencarb and the potential effect of SMC treatment was investigated by using comet assay. The observed results were presented in Table 2 and Figure 2. Regarding to the comet parameters in control fish group gills, Comet\%, Head Diameter, DNA \% Head, Tail Length, DNA \% Tail and Tail Moment were $13.99 \%, 20.29,82.3 \%, 5.8,19.32 \%$ and 1.34, respectively. Fish group treated with thiobencarb indicated a significant increase $(\mathrm{P}<0.05)$ in the values of Comet \% $(18.45 \%)$, Head Diameter $(25.5)$, Tail Length (7.59), DNA \% Tail (23.5\%), Tail Moment (2.47) and significant decrease in DNA \% Head value (76.91\%). The fish group treated with SMC in conjunction with thiobencarb indicated significantly ameliorated DNA damage effects exerted on gill tissue compared to thiobencarb treated fish group. the comet criteria in the fourth fish group which treated with SMC alone represented non significantly difference $(\mathrm{P}>0.05)$ with control values of Comet \% (13.2\%) and DNA \%Head $(82.17 \%)$, while significant difference $(\mathrm{P}<0.05)$ in Head Diameter $(18.28)$, Tail Length (5.26), DNA $\%$ Tail $(18.02 \%)$ and Tail Moment (1\%) was observed which indicated that the DNA damage in SMC group was rarely than the control group. Observational data of comet parameters evaluating the DNA damage effects in hepatic cells of thiobencarb and SMC treated fishes clarified a significant increase $(\mathrm{P}<0.05)$ in Comet \% $(13.6 \%)$, Head Diameter (24.44), Tail Length (7.07), DNA \% Tail (22.7\%) and Tail Moment (2.22) compared to the control group values including Comet \% (12.4\%), Head Diameter (20.87), Tail Length (4.72), DNA \% Tail (19.94 \%) and Tail Moment (1.35) and significant decrease $(\mathrm{P}<0.05)$ in DNA \% Head $(75.82 \%)$ compared to control $(79.63 \%)$ value. A repair in DNA damage was observed in fish treated with Thiobencarb+SMC which were evidenced by improved comet values in this group compared to the thiobencarb treated group. All comet variables for hepatic cells of fish treated with SMC exhibited non significantly differences $(\mathrm{P}>0.05)$ with the same parameters in the control group.

\section{Histopathological findings}

The histopathological findings were illustrated in Figure 3 and scoring of the lesions was mentioned in Table 3. The liver of the control fish presented normal hepatic and pancreatic tissues. The hepatic tissues consisted of normal hepatocytes with irregular hepatic vacuolation consistent with physiological glycogen storage. The pancreatic tissue was distributed within the hepatic tissues and enclosed venous blood supply. The thiobencarb treated fish presented marked decrease in hepatic vacuolation, marked increase in number of hepatocytes within the examined field, hyperplasia and single cell necrosis within the pancreatic portion. The SMC treated fish had normal hepatic and pancreatic tissues. The Thiobencarb and SMC treated fish demonstrated marked decrease in mitogenic effect which represented with decrease in number of hepatocytes. The gills of control fish revealed normal primary and secondary gill lamellae. Marked loss of secondary gill lamellae associated with necrosis of the lamellae, infiltration of leukocytes and proliferation of goblet cells were noticed within the gills of the intoxicated group. The gills of SMC treated fish were within the normal limits. The intoxicated and SMC treated fish revealed marked decrease in the adhesion of the secondary lamellae and appearance of the secondary gill lamellae. The brain of the normal fish indicated normal nerve cells and nerve fibers. The thiobencarb treated fish revealed multifocal malacia associated with marked gliosis and appearance of gitter-like cells. The brain of SMC treated was normal. The brain of thiobencarb intoxicated fish and SMC treated revealed limited malacic foci with marked decrease in the glia and gitter cells.

Table 2. DNA damage assessed by comet assay in liver and gills of Oreochromis niloticus exposed to thiobencarb (36 $\mu \mathrm{g} / \mathrm{L})$ and SMC (200 mg/kg ration) compared with control non treated fish

\begin{tabular}{|c|c|c|c|c|c|c|c|}
\hline & Groups & Comet \% & Head diameter & DNA \% Head & Tail length & DNA \% Tail & Tail moment \\
\hline \multirow{4}{*}{ Gills } & Control & $13.99 \pm 0.155^{\mathrm{c}}$ & $20.29 \pm 0.631^{\mathrm{c}}$ & $82.30 \pm 0.994^{\mathrm{a}}$ & $5.80 \pm 0.119^{\mathrm{c}}$ & $19.32 \pm 0.196^{\mathrm{c}}$ & $1.34 \pm 0.054^{\mathrm{b}}$ \\
\hline & Thiobencarb & $18.45 \pm 0.370^{\mathrm{a}}$ & $25.50 \pm 0.350^{\mathrm{a}}$ & $76.91 \pm 0.601^{\mathrm{c}}$ & $7.59 \pm 0.143^{\mathrm{a}}$ & $23.50 \pm 0.407^{\mathrm{a}}$ & $2.47 \pm 0.134^{\mathrm{a}}$ \\
\hline & Thiobencarb + SMC & $15.90 \pm 0.448^{\mathrm{b}}$ & $22.64 \pm 0.495^{\mathrm{b}}$ & $79.96 \pm 0.275^{\mathrm{b}}$ & $6.40 \pm 0.039^{\mathrm{b}}$ & $21.28 \pm 0.292^{\mathrm{b}}$ & $1.47 \pm 0.112^{\mathrm{b}}$ \\
\hline & SMC & $13.20 \pm 0.465^{\mathrm{c}}$ & $18.28 \pm 0.362^{\mathrm{d}}$ & $82.17 \pm 0.365^{\mathrm{a}}$ & $5.26 \pm 0.067^{\mathrm{d}}$ & $18.02 \pm 0.185^{\mathrm{d}}$ & $1.00 \pm 0.034^{\mathrm{c}}$ \\
\hline \multirow{4}{*}{ Liver } & Control & $12.04 \pm 0.168^{\mathrm{bc}}$ & $20.87 \pm 0.540^{b}$ & $79.63 \pm 1.144^{\mathrm{ab}}$ & $4.72 \pm 0.335^{\mathrm{bc}}$ & $19.94 \pm 0.495^{\mathrm{bc}}$ & $1.35 \pm 0.052^{\mathrm{c}}$ \\
\hline & Thiobencarb & $13.60 \pm 0.240^{\mathrm{a}}$ & $24.44 \pm 0.342^{\mathrm{a}}$ & $75.82 \pm 1.160^{\mathrm{c}}$ & $7.07 \pm 0.121^{\mathrm{a}}$ & $22.07 \pm 0.525^{\mathrm{a}}$ & $2.22 \pm 0.109^{\mathrm{a}}$ \\
\hline & Thiobencarb + SMC & $12.47 \pm 0.428^{\mathrm{b}}$ & $20.31 \pm 0.781^{\mathrm{b}}$ & $78.76 \pm 0.622^{\mathrm{b}}$ & $5.53 \pm 0.455^{\mathrm{b}}$ & $20.39 \pm 0.398^{\mathrm{b}}$ & $1.80 \pm 0.062^{\mathrm{b}}$ \\
\hline & SMC & $11.50 \pm 0.212^{\mathrm{c}}$ & $19.08 \pm 0.672^{\mathrm{b}}$ & $82.23 \pm 0.613^{\mathrm{a}}$ & $4.27 \pm 0.418^{c}$ & $18.67 \pm 0.381^{\mathrm{c}}$ & $1.12 \pm 0.064^{\mathrm{c}}$ \\
\hline
\end{tabular}

* Means with different superscripts in each column are significantly differ at $\mathrm{P}<0.05$. SMC means S-Methyl Cysteine 
Table 3. Semi quantitative scoring of the lesions within the liver, gills and kidney of Oreochromis niloticus exposed to thiobencarb $(36 \mu \mathrm{g} / \mathrm{L})$ and SMC $(200 \mathrm{mg} / \mathrm{kg}$ ration $)$ compared with control non treated fish

\begin{tabular}{lccccccc}
\hline & \multirow{2}{*}{ Organs } & \multicolumn{2}{c}{ Liver } & \multicolumn{2}{c}{ Gills } & \multicolumn{2}{c}{ Brain } \\
\cline { 3 - 7 } & Degeneration & Hyperplasia & Adhesion & Inflammation & Malacia & Inflammation \\
\hline Control & - & - & - & - & - & - \\
Thiobencarb & ++ & ++++ & ++++ & +++ & ++++ & +++ \\
SMC & - & - & - & - & - & - \\
SMC+Thiobencarb & + & ++ & ++ & + & + & + \\
\hline
\end{tabular}

,,++++++ and ++++ indicate mild, moderate, severe and focal, severe and diffuse lesions respectively. SMC means S-Methyl Cysteine
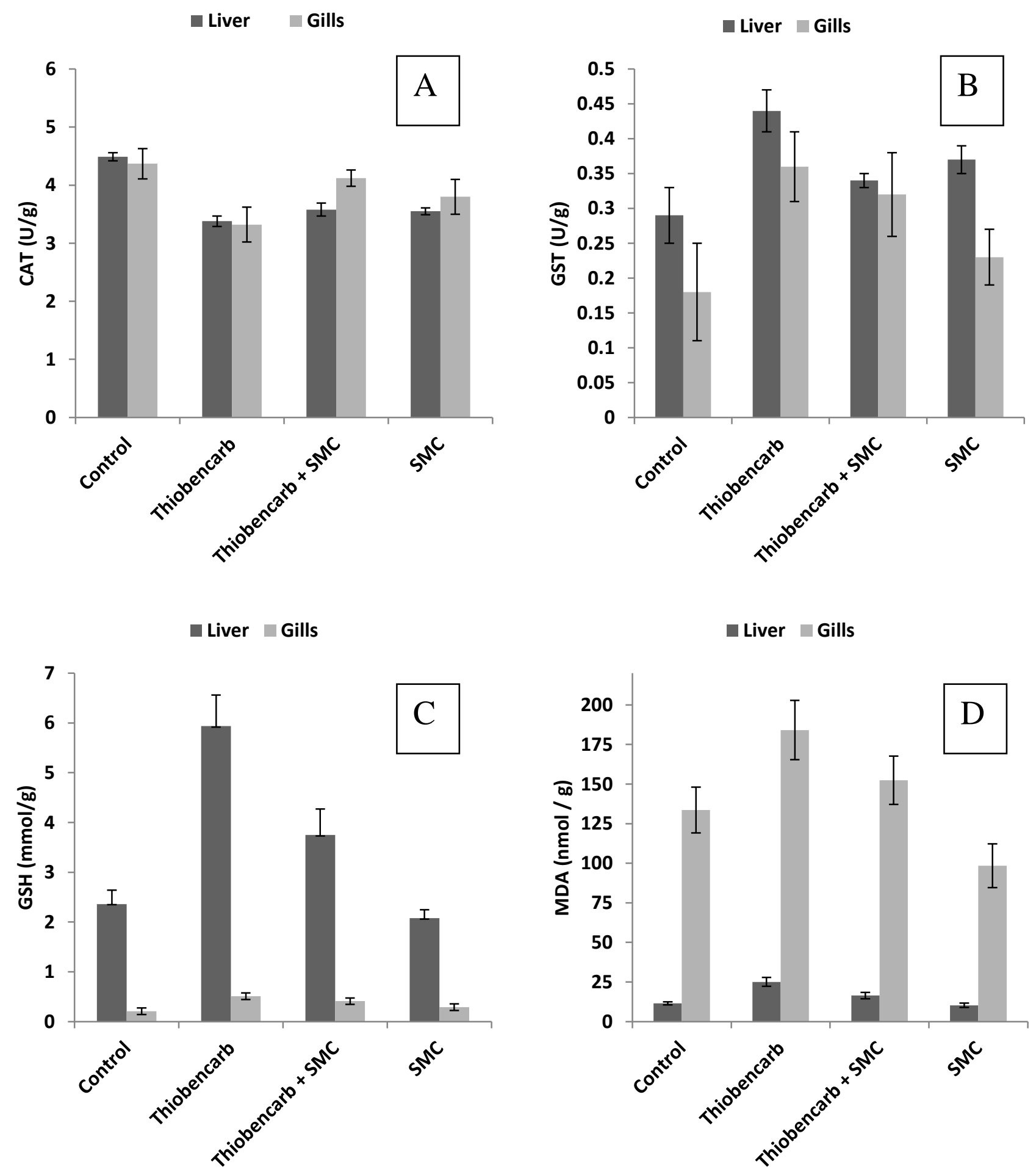

Figure1. Antioxidant biomarkers values in experimental fish (Oreochromis niloticus) groups A, B, C and D refers to Catalase, Glutathione S Transferase, Glutathione reduced and Malondialdhyde respectively. SMC refers to S-Methyl Cysteine 


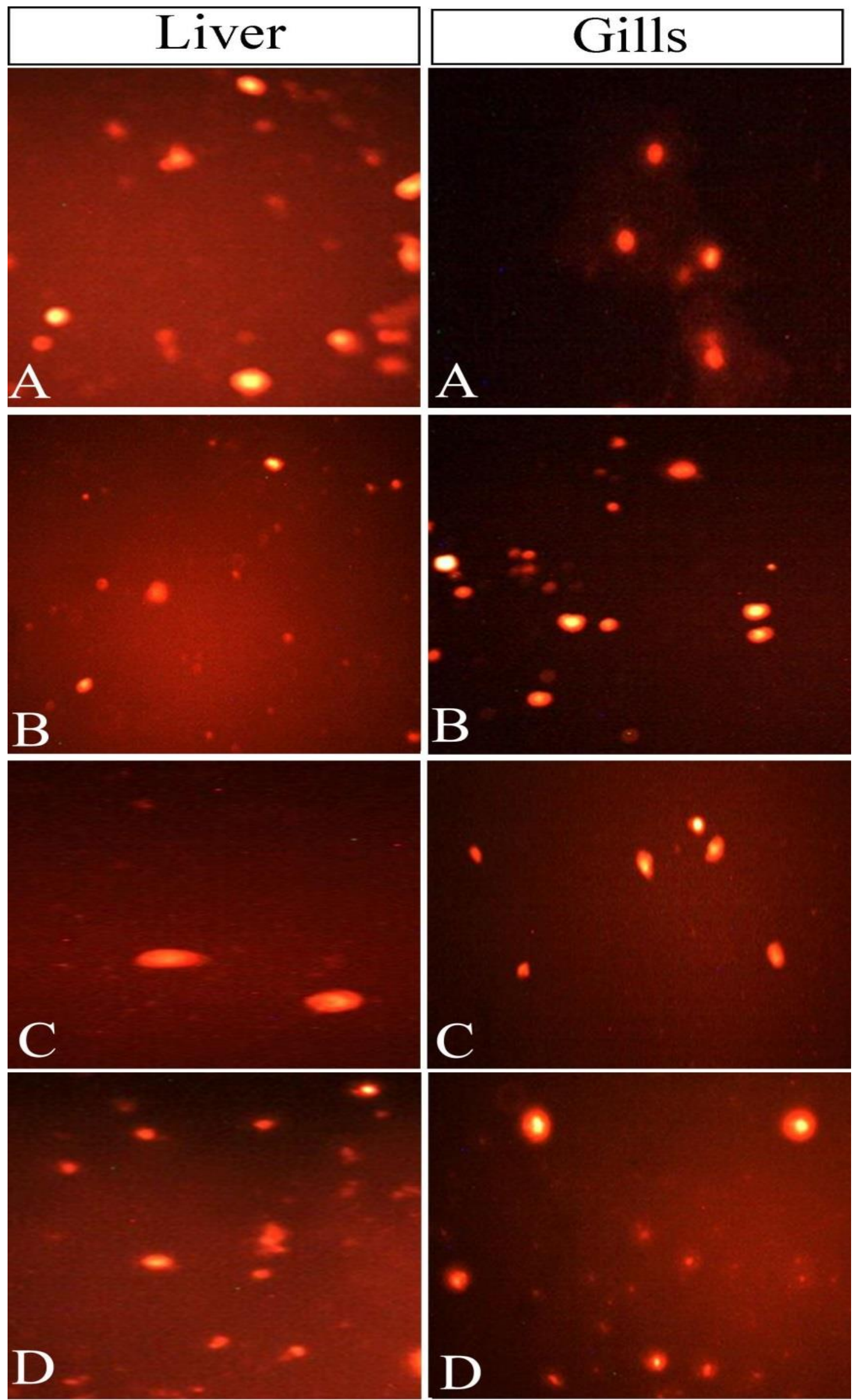

Figure 2. Photomicrograph by using comet assay showing the different degrees of DNA damage in liver and gills of Oreochromis niloticus exposed to thiobencarb $(36 \mu \mathrm{g} / \mathrm{L})$ and SMC (200 mg/kg ration) compared with control non treated fish. (A), (B), (C), (D) refers to control, Thiobencarb, Thiobencarb+ S-Methyl Cysteine and S-Methyl Cysteine treated fish groups respectively. (Ethidium bromide X40) 


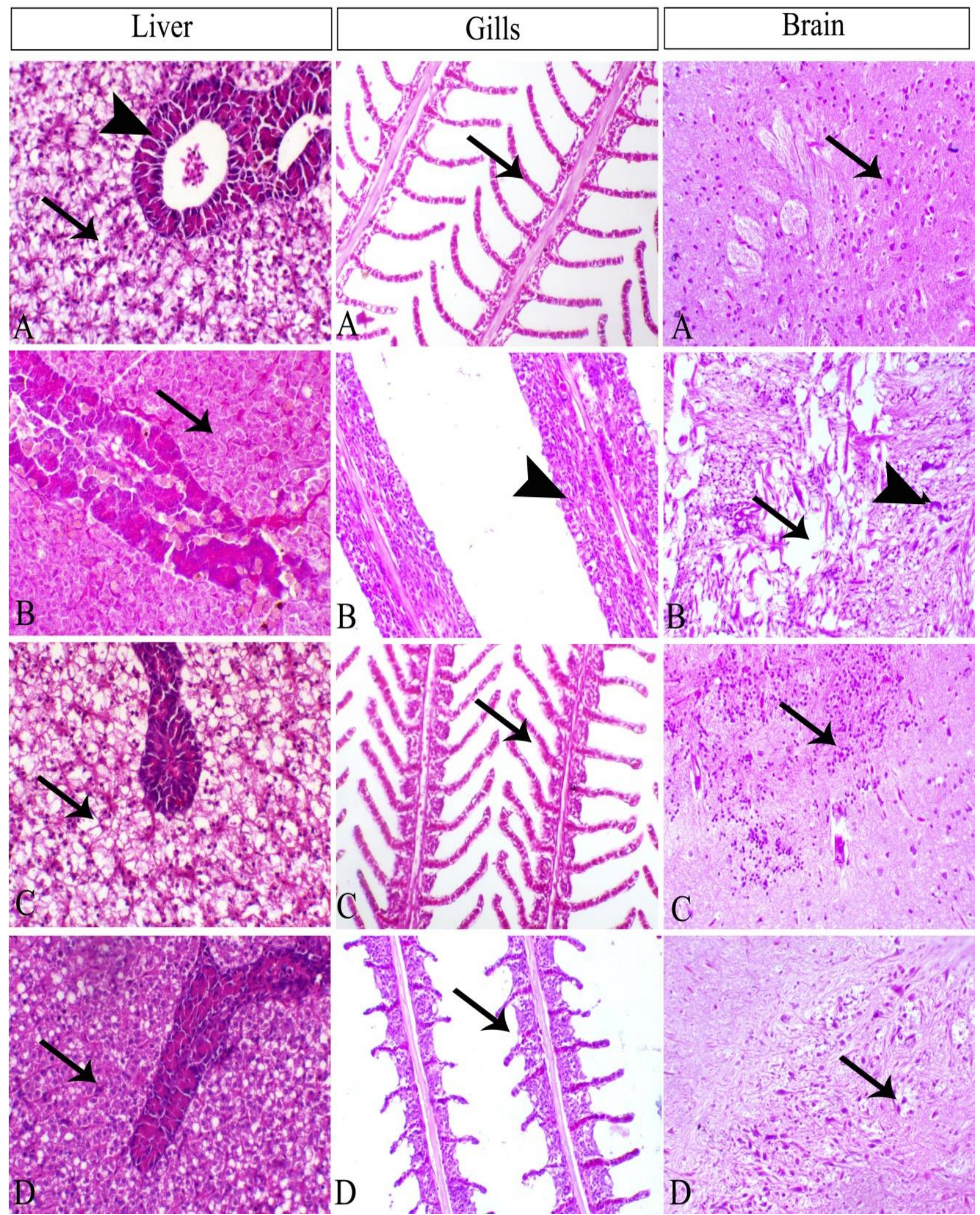

Figure 3. Histopathological changes in liver, gills and brain of Oreochromis niloticus exposed to thiobencarb (36 $\mu \mathrm{g} / \mathrm{L})$ and SMC (200 mg/kg ration) compared with non-treated fish. The liver of control fish (A) showing normal hepatic (arrow) and pancreatic tissues (arrowhead) (the hepatocytes revealing normal vacuolation consistent with glycogen storage), the liver of thiobencarb-treated fish (B) showing marked increase of hepatocytes indicated with increase the number of nuclei (arrow), the liver of normal fish treated with SMC (C) showing normal hepatic (arrow) and pancreatic tissues, and the liver of thiobencarb and SMCtreated fish (D) showing marked decrease the number of the proliferated hepatocytes (arrow), H\&E, X200. The gills of control fish (A) showing secondary gill lamellae (arrow), the gill of thiobencarb-treated fish (B) showing marked loss and adhesion of the secondary lamellae (arrow) with increased number of mucous cells, the gill of normal fish treated with SMC (C) showing lamellae tissues (arrow), and the gills of thiobencarb and SMC-treated fish (B) showing marked decrease the adhesion of the secondary lamellae (arrow), H\&E, X200. The brain (telencephalon portion) of control fish (A) showing normal neuronal cells and with normal nerve fibers (arrow), the brain of thiobencarb-treated fish (B) showing malacia (arrow) and gliosis (arrowhead), the brain of normal fish treated with SMC (C) showing neuronal tissues with normal glia cells (arrow), and the brain of thiobencarb and SMC-treated fish (B) showing marked decrease the necrotic changes and neuronal vacuolation (arrow), H\&E, X200. 
Aquatic environments contamination level with various chemicals has been increased in Egypt during the last years, which may be attributed to the intensive use of chemicals in the agricultural field (Dahshan et al., 2016). Chemical herbicides are a group of widely spread pesticides used for control of exotic weeds, which may be selective or nonselective. Thiobencarb is one of the intensively used selective herbicides in Egypt, which used primarily for the weeds emerging in the rice fields (Tanetani et al., 2013). Furthermore, the uncontrolled use of these chemicals during rice cultivation season poses a crucial source of aquatic environments pollution (Sapari and Ismail, 2012), it finds their way to the near water bodies through the surface runoff (Phong et al., 2006; Papadakis et al., 2015) causing adverse impacts on aquatic livings ranging from mild effects to life threatening ones (Bailey, 1993).

Fish are one of the most important aquatic organisms affected by water chemical pollution (Sommer, 1983). Moreover, it has been considered as a highly sensitive indicator for aquatic environment contamination (Singh et al., 1988). However, previous studies pointed out the adverse effects of water chemical pollutants particularly herbicides in different fish species (Nwani et al., 2011). Oreochromis niloticus was selected as an indicator for water pollution (Bacolod et al., 2017). Additionally, fish represent different adverse effects from thiobencarb herbicides (Bailey, 1993; Fernández-Vega et al., 1999; Saka, 2010).

This study pointed out the genotoxic effect of thiobencarb exerted on erythrocytes of Oreochromis niloticus which was obvious by significantly increased $(\mathrm{P}<0.05)$ micronuclei and nuclear abnormalities in thiobencarb treated fish. Moreover, the genotoxic effect was cleared in hepatic and gill tissues by significant increase $(\mathrm{P}<0.05)$ of comet parameters (Comet \%, Head Diameter, Tail Length, DNA \%Tail and Tail Moment) and significant decrease $(\mathrm{P}<0.05)$ of DNA \%Head in thiobencarb treated fish compared to control group. Genotoxic effect may be attributed to the oxidative stress of the herbicide (Lima et al., 2006; Bacolod et al., 2017) which was ensured by significantly different antioxidant biomarkers in present results. Furthermore, this adverse toxic effect was reflected on the results of histopathological examination of liver, gills and brain of thiobencarb exposed fish. Hepatic section showed hyperplasia and single cell necrosis, while gills examination revealed marked loss of secondary gill lamellae associated with extensive necrosis of the lamellae, infiltration of leukocytes and proliferation of goblet cells. Also, multifocal malacia associated with marked gliosis and appearance of gitter-like cells was observed in brain tissue of intoxicated fish. The present study results were in line with Elias et al. (2020).

Herbicides induces oxidative stress remains the principal way for production of Reactive Oxygen Species (ROS) which may provoke oxidative damage to DNA, protein and lipids. The ROS detoxification is done by antioxidant system (Fan et al., 2013). Therefore, ROS detoxification failure prompts serious implication on cellular structure, function and life (Bacolod et al., 2017) which was clearly seen in tested parameters of thiobencarb intoxicated fish. The gills are the largest contacting organ of fish with the environment, which play the prime role in fish respiration, osmoregulation, and considered as a crucial part in fish excretion system (Simonato et al., 2008). However, the gills represent the first chief organ critically affected by water contamination, from this stand point the results revealed an elevation in GST activity and GSH level in the gills of intoxicated fish, which means that GST as well as GSH had an important role in thiobencarb detoxification.

SMC is an organosulfur compound naturally found in some plants particularly garlic (Allium sativum). A promising protective role of SMC had been prophesied as anti-apoptotic (Nasr et al., 2017), antidiabetic (Senthilkumar et al., 2013) and anticancer (Fukushima et al., 2001). Sulfur is a crucial component of various cellular proteins impacting the cell health particularly by enzymatic and non-enzymatic antioxidant molecules like glutathione and thioredoxin (Atmaca, 2004). In present study, fish exposed to thiobencarb and fed on ration containing SMC presented a curing effect based on the antioxidant biomarkers. The CAT activity was elevated, GST activity was corrected and MDA level was decreased, while sulfur dependent GSH was elevated after treatment with SMC compared with thiobencarb intoxicated fish. SMC ameliorated the oxidative DNA damage based on the correction of erythrocytes micronucleus and abnormal nuclei frequencies and comet parameters. Moreover, histopathological finding in gills, liver and brain of thiobencarb intoxicated fish were disappeared in SMC treated fish.

\section{CONCLUSION}

Oreochromis niloticus were sensitive to thiobencarb contamination which was explained by genotoxic and oxidative damage effects. Moreover, histopathological changes related to herbicide impact were recorded. These adverse toxic effects were ameliorated by S-Methyl Cysteine (SMC). Therefore, controlling of thiobencarb which is used as herbicide in rice fields should be done wisely. In addition, careful monitoring of thiobencarb should be carried out to minimize its adverse impacts on the aquatic ecosystems. S-Methyl Cysteine would be helpful for alleviating the toxic effects exerted by thiobencarb on Oreochromis niloticus. This study should be supported by more field studies to point out the effects of natural factors of aquatic environment on the use of SMC. 


\section{DECLARATIONS}

\section{Acknowledgments}

The authors would like to thank Mahmoud S.El-Tarabany, Department of Animal Wealth Development, Faculty of Veterinary Medicine, Zagazig University, Zagazig, Egypt for his assistance in statistical analysis of this study.

\section{Competing interests}

The authors have not declared any conflict of interest.

\section{Author's contribution}

Mostafa Elmadawy, Walied Abdo, Amira Omar, and Nadia Mahfouz designed the study. Mostafa Elmadawy and Amira Omar performed the experiments. Walied Abdo and Nadia Mahfouz supervised the laboratory examinations. Histopathological examination was carried out by Walied Abdo. All authors prepared, read and approved the final manuscript.

\section{Consent to publish \\ Not applicable}

\section{REFERENCES}

Aebi H (1984). Catalase in vitro. Methods in Enzymology, 105: 121-126. DOI: https://doi.org/10.1016/S0076-6879(84)05016-3.

Al-Sabti K, and Metcalfe CD (1995). Fish micronuclei for assessing genotoxicity in water. Mutation Research/Genetic Toxicology, 343(2-3): 121-135. DOI: https://doi.org/10.1016/0165-1218(95)90078-0

Anderson D (2005). Male-mediated developmental toxicity. Toxicology and Applied Pharmacology, 207: 506-513. DOI: https://doi.org/10.1016/j.taap.2005.01.022

Atmaca G (2004). Antioxidant effects of sulfur-containing amino acids. Yonsei Medical Journal, 45: 776-788. DOI: https://doi.org/10.3349/ymj.2004.45.5.776

Bacolod ET, Uno S,Villamor SS, and Koyama J (2017). Oxidative stress and genotoxicity biomarker responses in tilapia (Oreochromis niloticus) exposed to environmental concentration of 1-nitropyrene. Marine Pollution Bulletin, 124(2): 786-791. DOI: https://doi.org/10.1016/j.marpolbul.2017.01.077

Bailey HC (1993). Acute and Chronic Toxicity of the Rice Herbicides Thiobencarb and Molinate to Opossum Shrimp (Neomysis mercedis). Marine Environmental Research, 36: 197-215. DOI: https://doi.org/10.1016/0141-1136(93)90089-I

Bancroft JD, and Layton C (2013). The haemtoxylins and eosin. Bancroft's Theory and practice of histological techniques, Expert consult: Online and print, 7: Bancroft's Theory and practice of histological techniques, p. 173.

Benfeito S, Silva T, Garrido J, Andrade PB, Sottomayor MJ, Borges F, and Garrido EM (2014). Effects of Chlorophenoxy Herbicides and Their Main Transformation Products on DNA Damage and cetylcholinesterase Activity. BioMed Research International, 2014: 709036. DOI: https://doi.org/10.1155/2014/709036

Beutler E, Duron O, and Kelly BM (1963). Improved method for the determination of blood glutathione. The Journal of laboratory and clinical medicine, 61: 882-888. PMID: 13967893.

Bombail V, Dennis AW, Gordon E, and Batty J (2001). Application of the comet and micronucleus assays to butterfish (Pholis gunnellus) erythrocytes from the Firth of Forth, Scotland. Chemosphere, 44: 383-392. DOI: https://doi.org/10.1016/S00456535(00)00300-3

Cavaş T, and Ergene-Gözükara S (2003). Micronuclei, nuclear lesions and interphase silver-stained nucleolar organizer regions (AgNORs) as cyto-genotoxicity indicators in Oreochromis niloticus exposed to textile mill effluent. Mutation Research/Genetic Toxicology and Environmental Mutagenesis, 538(1-2): 81-91. DOI: https://doi.org/10.1016/S1383-5718(03)00091-3

Dahshan H, Megahed AM, Abd-Elall AM, Abd-El-Kader MA, Nabawy E, and Elbana MH (2016). Monitoring of pesticides water pollution-The Egyptian River Nile. Journal of Environmental Health Science and Engineering, 14: 15. DOI: https://doi.org/10.1186/s40201-016-0259-6

Elias NS, Abouelghar GE, Sobhy HM, El Miniawy HM, and Elsaiedy EG (2020). Sublethal effects of the herbicide thiobencarb on fecundity, histopathological and biochemical changes in the African catfish (Clarias gariepinus). Iranian Journal of Fisheries Sciences, 19(3): 1589-1614. DOI: https://doi.org/10.22092/ijfs.2018.119669

El-Magd MA, Abdo WS, El-Maddaway M, Nasr NM, Gaber RA, El-Shetry ES, Saleh AA, Alzahrani FAA, and Abdelhady DH (2017). High doses of S-methylcysteine cause hypoxia-induced cardiomyocyte apoptosis accompanied by engulfment of mitochondaria by nucleus. Biomedicine \& Pharmacotherapy, 94: 589-597. DOI: https://doi.org/10.1016/j.biopha.2017.07.100

Fan JY, Geng JJ, Ren HQ, Wang XR, and Han C (2013). Herbicide Roundup and its main constituents cause oxidative stress and inhibit acetylcholinesterase in liver of Carassius auratus. Journal of Environmental Science and Health B, 48 (10): 844-850. https://doi.org/10.1080/03601234.2013.795841.

Fernández-Vega C, Sancho E, Ferrando MD, and Andreu-Moliner E (1999). Thiobencarb toxicity and plasma AChE inhibition in the European eel. Journal of Environmental Science and Health, Part B Pesticides, Food Contaminants and Agricultural Wastes, 34(1): 61-73. DOI: https://doi.org/10.1080/03601239909373184

Fukushima S, Takada N, Wanibuchi H, Hori T, Min W, and Ogawa M (2001). Suppression of chemical carcinogenesis by watersoluble organosulfur compounds. The Journal of Nutrition, 131(3s): 1049S-1053S. DOI: https://doi.org/10.1093/jn/131.3.1049S 
Gorell JM, Jhonson CC, Rybicki BA, Peterson EL, and Ricchardson RJ (1998). The Risk of Parkinson's disease with exposure to pesticides, farming, well water, and rural living. Neurology, 50(5): 1346-1350. DOI: https://doi.org/10.1212/WNL.50.5.1346

Habig WH, Pabst MJ, and Jakoby WB (1974). Glutathione S-transferases. The first enzymatic step in mercapturic acid formation. The Journal of Biological Chemistry, 25; 249(22): 7130-7139. Available at: https://www.jbc.org/content/249/22/7130.long

Hakim MA, Juraimi AS, Hanafi MM, Rafii MY, Ismail MR, Karim SM, and Kausar H (2015). Integration of herbicides with manual weeding for controlling the weeds in rice under saline environment. Journal of Environmental Biology, 36(6): 1311-1317. Available at: http://www.jeb.co.in/journal_issues/201511_nov15/paper_10.pdf

Hladik ML, Bouwer EJ, and Roberts AL (2008). Neutral degradates of chloroacetamide herbicides: Occurrence in drinking water and removal during conventional water treatment. Water Research, 42(20): 4905-4914. DOI https://doi.org/10.1016/j.watres.2008.09.008

Ishikawa K, Nakamura Y, and Kuwatsuka S (1977). Photodegradation of benthiocarb herbicide. Journal of Pesticide Science, $2: 17-$ 25. Available at: https://www.jstage.jst.go.jp/article/jpestics1975/2/1/2_1_17/_pdf

Kandiel MM, El-Asely AM, Radwan HA, and Abbass AA (2014). Modulation of genotoxicity and endocrine disruptive effects of malathion by dietary honeybee pollen and propolis in Nile tilapia (Oreochromis niloticus). Journal of Advanced Research, 5(6): 671-684. DOI: https://doi.org/10.1016/j.jare.2013.10.004

Lima PL, Benassi JC, Pedrosa RC, Dal Magro J, Oliveira TB, and Wilhelm Filho D (2006). Time-course variations of DNA damage and biomarkers of oxidative stress in tilapia (Oreochromis niloticus) exposed to effluents from a swine industry. Archives of Environmental Contamination and Toxicology, 50(1): 23-30. DOI: https://doi.org/10.1007/s00244-004-0178-x

Monteith DK, and Vanstone J (1995). Comparison of the microgel electrophoresis assay and other assays for genotoxicity in the detection of the DNA damage. Mutation Research, 345(3-4): 97-103. DOI: https://doi.org/10.1016/0165-1218(95)90045-4

Munger R, Isacson P, Hu S, Burns T, Hanson J, Lynch CF, Cherryholmes K, Vandorpe P, and Hausler Jr WJ (1997). Intrauterine growth retardation in Iowa communities with herbicides-contaminated drinking water supplies. Environmental Health Perspectives, 105: 308-314. DOI: https://doi.org/10.1289/ehp.97105308

Nasr EN, Elmadawy MA, Almadaly EA, Abdo W, and Zamel MM (2017). Garlic Powder Attenuates Apoptosis Associated with Lead Acetate-Induced Testicular Damage in Adult Male Rats. Alexandria Journal of Veterinary Sciences, 54(1): 70-78. DOI: https://doi.org/10.5455/ajvs.268149

Nicolopoulou-Stamati P, Maipas S, Kotampasi C, Stamatis P, and Hens L (2016). Chemical Pesticides and Human Health: The Urgent Need for a New Concept in Agriculture. Frontiers in Public Health, 18(4): 148. DOI: https://doi.org/10.3389/fpubh.2016.00148

Nwani CD, Nagpure NS, Kumar R, Kushwaha B, Kumar P, and Lakra WS (2011). Mutagenic and genotoxic assessment of atrazinebased herbicide to freshwater fish Channa puntatus (Bloch) using micronucleus test and single cell gel electrophoresis. Environmental Toxicology and Pharmacology, 31: 314-322. DOI: https://doi.org/10.1016/j.etap.2010.12.001

Ohkawa H, Ohishi N, and Yagi K (1979). Assay for lipid peroxides in animal tissues by Thiobarbituric acid reaction. Analytical Biochemistry, 95(2): 351-358. DOI: https://doi.org/10.1016/0003-2697(79)90738-3

Papadakis EN, Vryzas Z, Kotopoulou A, Kintzikoglou K, Makris KC, and Papadopoulou-Mourkidou E (2015). A pesticide monitoring survey in rivers and lakes of northern Greece and its human and ecotoxicological risk assessment. Ecotoxicology and Environmental Safety, 116: 1-9. DOI: https://doi.org/10.1016/j.ecoenv.2015.02.033

Phong TK, Nguyen MH, Komany S, Vu SH, and Watanabe H (2006). Alternative water management for controlling simetryn and thiobencarb runoff from paddy fields. Bulletin of Environmental Contamination and Toxicology, 77(3): 375-382. DOI: https://doi.org/10.1007/s00128-006-1076-x

Recio L, Hobbs C, Caspary W, and Witt KL (2010). Dose-Response Assessment of Four Genotoxic Chemicals in a Combined Mouse and Rat Micronucleus and Comet Assay Protocol. The Journal of Toxicological Sciences, 35(2): 149-162. DOI: https://doi.org/10.2131/jts.35.149

Saka M (2010). Acute toxicity of rice paddy herbicides simetryn, mefenacet, and thiobencarb to Silurana tropicalis tadpole. Ecotoxicology and Environmental Safety, 73(6): 1165-1169. DOI: https://doi.org/10.1016/j.ecoenv.2010.05.008

Sanderson JT, Letcher RJ, Heneweer M, Giesy JP, and Van den Berg M (2001). Effects of chloro-s-triazine herbicides and metabolites on aromatase activity in various human cell lines and on vitellogenin production in male carp hepatocytes. Environmental Health Perspectives, 109(10): 1027-1031. DOI: https://doi.org/10.1289/ehp.01109102712

Sapari P, and Ismail BS (2012). Pollution levels of thiobencarb, propanil, and pretilachlor in rice fields of the muda irrigation scheme, Kedah, Malaysia: Environmental Monitoring and Assessment, 184(10): 6347-6356. DOI: https://doi.org/10.1007/s10661-0112424-9.

Senthilkumar PS, Thomas S, Sivaraman K, Sankar P, and Bobby Z (2013). Study the effect of s-methyl L-cysteine on lipid metabolism in an experimental model of diet induced obesity. Journal of Clinical and Diagnostic Research, JCDR 7 (11): 24492451. DOI: https://doi.org/10.7860/JCDR/2013/7304.3571.

Sikka HC, Rutkowski JP, Kandaswami C, Kumar S, Earley K, and Gupta RC (1990). Formation and persistence of DNA adducts in the liver of brown bullheads exposed to benzo[a]pyrene, Cancer Letters, 49: 81-87. DOI: https://doi.org/10.1016/0304$\underline{3835(90) 90142-\mathrm{k}}$.

Silva V, Mol HGJ, Zomer P, Tienstra M, Ritsema CJ, and Geissen V (2019). Pesticide residues in European agricultural soils - A hidden reality unfolded. Science of the Total Environment, 25;653: 1532-1545. DOI: https://doi.org/10.1016/j.scitotenv.2018.10.441.

Simonato JD, Guedes CLB, and Martinez CBR (2008). Biochemical, physiological, and histological changes in the neotropical fish Prochilodus lineatus exposed to diesel oil. Ecotoxicology and Environmental Safety, 69: 112-120. DOI: https://doi.org/10.1016/j.ecoenv.2007.01.012.

Singh NP, McCoy MT, Tice RR, and Schneider EL (1988). A simple technique for quantitation of low levels of DNA damage in individual cells. Experimental Cell Research, 175: 184-191. DOI: https://doi.org/10.1016/0014-4827(88)90265-0. 
Sommer TR (1983). Laboratory and field studies on the toxic effects of thiobencarb (bolero) to the crawfish Procambarus clarkia. Journal of the World Mariculture Society, 14: 434-440. DOI: https://doi.org/10.1111/j.1749-7345.1983.tb00095.x

Stein JE, Reichert WL, French B, and Varanasi U (1993). 32p-postlabeling analysis of DNA adduct formation and persistence in English sole exposed to benzo[a]pyrene and 7H-dibenzo(c,g)-carbazole. Chemico-Biological Interactions, 88: 55-69. DOI: https://doi.org/10.1016/0009-2797(93)90084-c.

Tanetani Y, Kaku K, Ikeda M, and Shimizu T (2013). Action mechanism of a herbicide, thiobencarb. Journal of Pesticide Science, 38(1): 39-43. DOI: https://doi.org/10.1584/jpestics.D12-047.

Valadas J, Mocelin R, Sachett A, Marcon M, Zanette RA, Dallegrave E, Herrmann AP, and Piato A (2019). Propiconazole induces abnormal behavior and oxidative stress in zebrafish. Environmental Science and Pollution Research, 26(27): 27808-27815. DOI: https://doi.org/10.1007/s11356-019-05977-3.

Van der Werf HMG (1996). Assessing the impact of pesticides on the environment. Agriculture, Ecosystems and Environment, 60: 81-96. DOI: https://doi.org/10.1016/S0167-8809(96)01096-1. 